\title{
PLASTIC WASTE FOR ELECTRICAL POWER GENERATION: A CASE STUDY IN NIGERIA
}

\author{
Olaide Monsor Aderoju1; Aliyu B. Oke²; Ganiy Ishola Agbaje ${ }^{3}$; António Guerner Dias ${ }^{4}$
}

ABSTRACT: Nigerian is currently threatened by the quantity of waste plastics in its major cities. However, waste plastics has been a menace to the Nigerian environs (land and water) majorly and contributed to flood disasters and other environmental degradation events which has led to severe health risk. In view of this, the study aims to assess the waste plastics in Nigeria for electric power generation. The study devised two strategies (incentive-based approach, and the Extended Producer's Responsibility (EPR)) for the collection of waste plastics from the environment. This study is focused on the incineration of waste plastics with energy recovery; hence the proximate and ultimate analyses were carried out to determine the Higher Heat Value (HHV) and the Lower Heat Value (LHV) as well as to estimate the Power Generation Potential (PGP). The empirical results show that the HHV was evaluated as $568.96 \mathrm{kcal} / \mathrm{kg}$ and, the LHV was evaluated as $561.55 \mathrm{kcal} / \mathrm{kg}$. Again, the power generation potential (PGP) was enumerated using 100 tons of waste plastics and 4.83 million tons ( $81 \%$ of inadequately managed plastics) to arrive at about $0.6 \mathrm{MW}$ and $29,000 \mathrm{MW}$ respectively. This study contributes to the literature on the problems of waste plastics in Nigeria. Furthermore, it is likely to be a sustainable solution to the backlog of waste plastics in the environment and a supplementary solution to the erratic electric power supply. The results show that the quantity of waste plastics in Nigeria is likely to generate enough electricity to complement the existing source of power supply.

KEYWORDS: incineration; municipal solid waste; waste to energy; waste plastics; power generation potential.

REsumo: Um dos grandes problemas da Nigéria, na atualidade, é a grande quantidade de resíduos plásticos que são produzidos nas suas principais cidades. Os resíduos plásticos têm sido uma ameaça para os arredores daquelas cidades (em particular sobre o solo e sobre a água) e contribuem para desastres de inundação e outros eventos de degradação ambiental que conduzem a sérios riscos para a saúde humana. Assim, este estudo tem como objetivo avaliar o potencial dos resíduos plásticos produzidos na Nigéria para a geração de energia elétrica. 0 estudo desenvolvido baseia-se em duas estratégias (uma abordagem baseada em incentivos e no princípio da Responsabilidade Estendida do Produtor (REP)) para a coleta de resíduos plásticos no meio ambiente. 0 foco deste trabalho está na incineração de resíduos plásticos com recuperação da energia produzida. Assim, foram realizadas análises imediata e elementar para determinar o Poder Calorífico Superior (PCS) e o Poder Calorífico Inferior (PCI), bem como estimar o Potencial de Geração de Energia (PGE). Os resultados empíricos mostram que o PCS foi avaliado em $568.96 \mathrm{kcal} /$ $\mathrm{kg}$ e o PCl foi avaliado em $561.55 \mathrm{kcal} / \mathrm{kg}$. Adicionalmente, foi determinado o Potencial de Geração de Energia (PGE) usando 100 toneladas de resíduos plásticos e 4.83 milhões de toneladas ( $81 \%$ de plásticos manuseados inadequadamente) obtendo-se, respetivamente, $0.6 \mathrm{MW}$ e $29.0 \mathrm{MW}$.
Este estudo contribui para a literatura como uma visão geral de gestão de resíduos na Nigéria, focando-se nos problemas relacionados com os resíduos plásticos. Além disso, o conceito proporciona uma solução sustentável para esta tipologia de resíduos que afeta particularmente a envolvente das grandes cidades. Além disso, é provável que seja uma solução sustentável para a acumulação de resíduos plásticos no meio ambiente e uma solução suplementar para a produção de energia elétrica. Os resultados mostram que a quantidade de resíduos plásticos produzidos na Nigéria, provavelmente, gerará eletricidade suficiente para complementar as fontes tradicionais de produção de eletricidade.

PALAVRAS-CHAVE: incineração; resíduos sólidos urbanos; resíduos para a produção de energia; resíduos plásticos; potencial de geração elétrica.

RESUMEN: Uno de los principales problemas de Nigeria hoy en día es la gran cantidad de residuos plásticos que se producen en sus principales ciudades. Los residuos plásticos han sido una amenaza para las afueras de esas ciudades (particularmente en el suelo y el agua) y contribuyen a los desastres de inundaciones y otros eventos de degradación ambiental que conducen a serios riesgos para la salud humana. Por lo tanto, este estudio tiene como objetivo evaluar el potencial de los residuos plásticos producidos en Nigeria para la generación de electricidad. El estudio desarrollado se basa en dos estrategias (un enfoque basado en incentivos y el principio de Responsabilidad Extendida del Productor (REP)) para la recolección de desechos plásticos en el medio ambiente. El objetivo de este trabajo es la incineración de residuos plásticos con la recuperación de la energía producida. Por lo tanto, se realizaron análisis inmediato y elemental para determinar el poder calorífico superior (PCS) y el poder calorífico inferior $(\mathrm{PCl})$, así como para estimar el potencial de generación de energía (PGE). Los resultados empíricos muestran que el PCS se calificó a $568.96 \mathrm{kcal} / \mathrm{kg}$ y el $\mathrm{PCl}$ se calificó a $561.55 \mathrm{kcal} / \mathrm{kg}$. Además, el potencial de generación de energía (PGE) se determinó utilizando 100 toneladas de residuos plásticos y 4,83 millones de toneladas ( $81 \%$ de plásticos manejados incorrectamente), produciendo respectivamente 0.6 MW y 29.0 MW. Este estudio contribuye a la literatura como una visión general de la gestión de residuos en Nigeria, centrándose en cuestiones relacionadas con los residuos plásticos. Además, el concepto proporciona una solución sostenible para esta tipología de residuos que afecta particularmente a los alrededores de las grandes ciudades. Los resultados muestran que la cantidad de residuos plásticos producidos en Nigeria probablemente generará electricidad suficiente para complementar las fuentes tradicionales de producción de electricidad.

PALABRAS-CLAVE: incineración; residuos sólidos urbanos; residuos para la producción de energía; residuos plásticos; potencial de generación de energía.

Olaide Monsor Aderoju (PhD in View in Environmental Science \& Technology at Faculdade de Ciências da Universidade do Porto, Porto - Portugal, E-mail: laideaderoju@gmail.com

2 Aliyu Bamidele Oke (Master’s in Chemical Engineering at National Space Research \& Development Agency- NASRDA. Abuja, FCT - Nigeria, E-mail: zayidali@ yahoo.com

3 Ganiy Ishola Agbaje (PhD in Geography-Geomatics at African Regional Centre for Space Science and Technology Education in English (ARCSSTE-E), Ile-Ife, Osun State-Nigeria, E-mail: gagbaje@yahoo.co.uk

4 António Guerner Dias (PhD in Geoscience at Universidade do Porto, Assistant Professor at Faculdade de Ciências da Universidade do Porto, Porto - Portugal, E-mail: agdias@fc.up.pt 


\section{INTRODUCTION}

Rapid population growth, booming economy, lifestyle, standard of living, rapid urbanization has accelerated Municipal Solid Waste (MSW) generation rate in developing countries (Minghua et al., 2009). According to UNU-WIDER (2010), solid waste management in developing countries has received less attention from policymakers and academics compared to other environmental problems. Globally, solid waste generation has soared in the past few decades and, it has resulted in the inability of waste management authorities to cope with the volume of solid waste generated and overstretching of waste management facilities (Nnaji, 2015). The current threat to global community is the quantity of waste plastics in the environment. In 1950 the world produced only 2 million tons per year. Since then, annual production has increased nearly 200-fold, reaching 38I million tons in 2015 (Geyer, Jambeck, \& Law, 20I7). Also, it was reported that the world's total consumption of plastics will reach 297.5 million tons by 2015 with an average growth rate of $5-6 \%$ (Huang, 2012; Somsak, 20I4).

Nigeria became an increasingly urbanized and urban-oriented society because of the oil boom in the rig7os (Aderoju, Guerner Dias \& Guimaraes, 2015). During the I97os, Nigeria had possibly the fastest urbanization growth rate in the world (Ochuo 1986). The World Bank (20I2) reported that Nigeria as a developing nation with a total urban population exceeding 70 million has its per capita generation of MSW as $0.56 \mathrm{~kg} / \mathrm{capita} /$ day and estimated projection is expected to be at 0.8 $\mathrm{kg} /$ capita/day by 2025 . Indeed, the impact of urban growth in Nigeria has led to an increasing volume and variety of MSW, resulting from increased flow of goods and services, and changed lifestyle and consumption pattern.

Waste management is an important objective of planning to ensure that the future generations inherit an environment that is as pollution free as possible given the present scientific, economic, social and political constraints (USEPA, 2005). Waste management in developing and developed nations differ in the waste composition, density, political and economic framework, and in waste amount, access to waste for collection, awareness, and attitudes (Ogwueleka, 2009). According to
(Nabegu, 20II), most cities across Nigeria, solid waste is disposed by transporting and discharging in open dumps location almost close to residential areas, which are environmentally unsafe. Current practice in Nigeria has shown that collection of MSW from homes, dump sites, and roadsides are the mandate of state and local government agencies. Waste density in Nigeria ranges from 280-370 $\mathrm{kg} / \mathrm{m}_{3}$ with waste generation rate of 25 million tons annually and at a daily rate of $0.44^{-0.66 \mathrm{~kg} /}$ individual daily (Ogwueleka, 2009). Nevertheless, Nigeria, like any other developing country has the informal sector (scavengers) who are highly committed to the collection and recovery of useful materials from waste streams in homes, market, dumps and landfills respectively.

There have been several studies on waste management, however, these studies were mostly focused on suitable location for waste disposal sites; outreach and education on waste management practices; effect of poor waste management practices; MSW characterization; energy recovery from waste among others. For instance; Nwambuonwo \& Mughele (2OI2) analyzed the existing landfill sites in Lagos, established the need for new dumpsites and proposed candidate landfill sites, using GIS with the World Bank criteria for siting a landfill. Also, Aderoju, Guerner Dias \& Anwasia (2016), utilized the (Aderoju conceptual model) ACM as a tool for awareness creation and education to the inhabitants of Kogi state, Nigeria to mitigate the events of flood disasters as a result of indiscriminate disposal of MSW into drainage ways and open fields. Babayemi \& Dauda (2009), focused on: the quantity and rate of solid waste generation in several cities in Nigeria; factors influencing the MSW generation; and, MSW characterization, collection and disposal pattern in Abeokuta, Nigeria with the aid of administered questionnaires. (Oumarou, Dauda, Abdulrahim \& Abubakar, 20I2) revealed that a comprehensive characterization of MSW is crucial to the long-term efficient and economical planning for solid waste management. MSW characterization plays an important role in the determination of the possible environmental impacts on nature as well as on society (Alamgir, Donald, Roehi, \& Ahsan, 2005). In a study by Rousta \& Dahlén, (2015), it was reported that inhabitants' participation in waste separation schemes seems crucial for the improvements 
needed to achieve a better ambitious material recycling goal, but there is no definite approach on how to design waste sorting and collection systems that engage inhabitants to increase their waste sorting. According to (Xu, Zhou, Lan, Jin \& Cao, 20I5), it was stated that an incentive-based source separation concept has influenced an increase in resource recovery whereby households receive an economic incentive for separating biodegradable and recyclable material from other waste streams, creating environmental and economic gains for the waste management sector. Jambeck et al. in (2015) combine available data on solid waste with a model that uses population density and economic status to estimate the amount of land-based plastic waste entering the ocean.

Studies have shown that plastics are the most difficult constituents of MSW in the environment because of its inability to decompose naturally. In a way to reduce the backlogs of waste plastics in Nigeria, this study aims to utilize the waste plastic for electric power generation. Furthermore, the study devised strategies to segregate and collect waste plastics from the environment to be utilize as fuel for electric power generation in a waste to energy process. This study is likely to reduce the quantity of waste plastics in the environment effectively, and it will also provide an alternative electric power source to Nigeria as a nation owing to the nation's low power supply to its inhabitants.

\section{THEORETICAL REFERENCE}

\section{I NIGERIAN APPROACH TO SOLID WASTE MANAGEMENT}

The approach used in the management of MSW in Nigeria is no difference to many developing nations. Currently, the common practice of waste collection, transportation, and disposal to a waste disposal site is often carried out by the authorities. However, inadequate service coverage for proper waste collection as only limited areas of the cities is covered (Nabegu, 2009). Limited budgets have compelled local agencies not to have adequate capacity to handle the increasing solid waste. Therefore, the common practice of MSW dumped in open spaces, drainage ways, water bodies, and on access roads has led to blockages in the waterways, streets littering, water body contamination, creating a breeding ground for vector causing diseases and rodents. According to
(Ogbonna, Ekweozor \& Ig, 2002), it was reported that little attention is given to some traditional suburban settlements for provision of waste collection and disposal services.

Currently, there are no formal recycling or resource recovery programmes in Nigeria (Ogwueleka, 2003) and no policy on composting. The recovery/recycling operations are carried out mostly by the informal sector which includes the scavengers and other used item vendors as a source of livelihood. Scavengers are driven by poverty and desire to earn a living. The practice is common in major cities and its suburbs whereby scavengers go to residential areas to purchase recyclables and condemned electronics from residence owners. Adebola (2006) reported that the vacuum that was created by selective services and irregular management of solid waste was filled by both the formal and informal private sector in solid waste management, while the formal private sector is made up of registered companies / enterprises who have the financial strength, some level of technical know-how/experience and are generally mechanized (see fig.2a and 2 b).

In the same study, Adebola also described the informal private sector as individuals, families, group or small enterprises that carry out unregistered, unregulated activities by going from Houseto-House waste collection transportation and recovery of useful materials from the waste stream (see fig. Ia and $\mathrm{rb}$ ). This sector provides employment opportunities for a large group of people.

Scavenging and recycling should be encouraged because it involves stakeholders such as; consumers/ scavengers, middlemen, and manufacturers. The scavengers (those involved in the on-site waste recovery or scavenging), the resource merchants (those involved in the purchase of all recovered recyclables and re-usable waste materials) and the recyclers (the micro and small scale recyclers that converts recovered materials like paper, animal by-products, plastic, metal among others to valuable materials and raw materials for the consumption of the industrial sector. Recycling is mostly carried out by segregation from mixed waste such that the sorting of waste stream to different classes (organic and inorganic) and furthermore by the collection crew from waste vehicles; and by scavengers, both from street bins and at the dumpsite. Scavengers normally have no formal education, inadequate capacity (technical know-how and equipment), and do not normally have alternative employment opportunities in the 
Figure 1. Formal Waste Management sector in Nigeria; (a) \& (b)

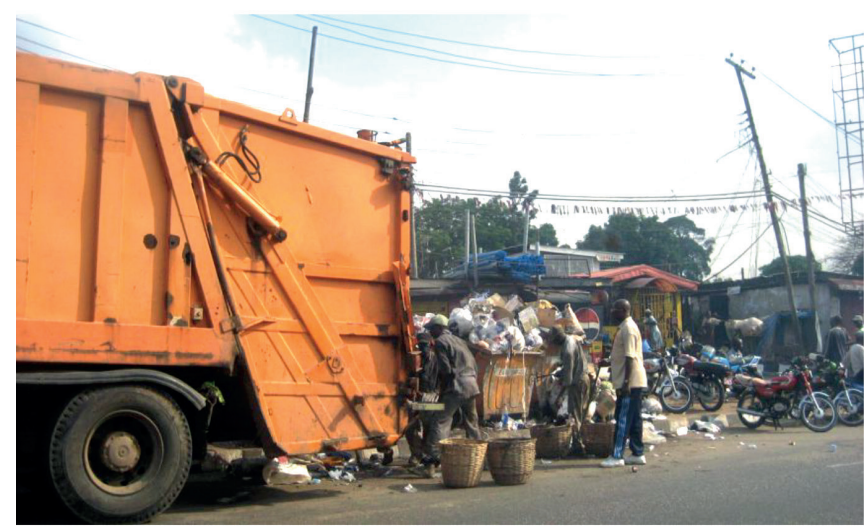

Source: (a) www.theglitters.com.ng

formal sector. The scavengers (see fig. $2 \mathrm{a}$ and $2 \mathrm{~b}$ ) and other informal sector recyclers generally sell their recovered materials to middlemen, who in turn sell to small- and large-scale processing and manufacturing industries. For example, collected glass is processed and recycled locally as cullet for use in the glass industry; whole bottles are cleaned and reused as syrup, drinks and juice containers; the bases of broken bottles are sold to small scale industries that cut and polish the glass to manufacture items such as ash trays and candle holders (Imam, Mohammed, Wilson \& Cheeseman, 2008).

The government of Lagos state, Nigeria through Lagos State Waste Management Agency (LAWMA) has embark on a private sector partnership (PSP) scheme to solve the MSW management issue in the state. The cooperation between the LAWMA and private operators is reported to have led to more efficient collection of waste from places of residency; the outsourcing of waste collection to the private sector under the PSP scheme may thus be considered as a significant improvement that has been made (Idowu, Omirin, \& Osagie, 2oII). According to the Nations newspaper of the ist of

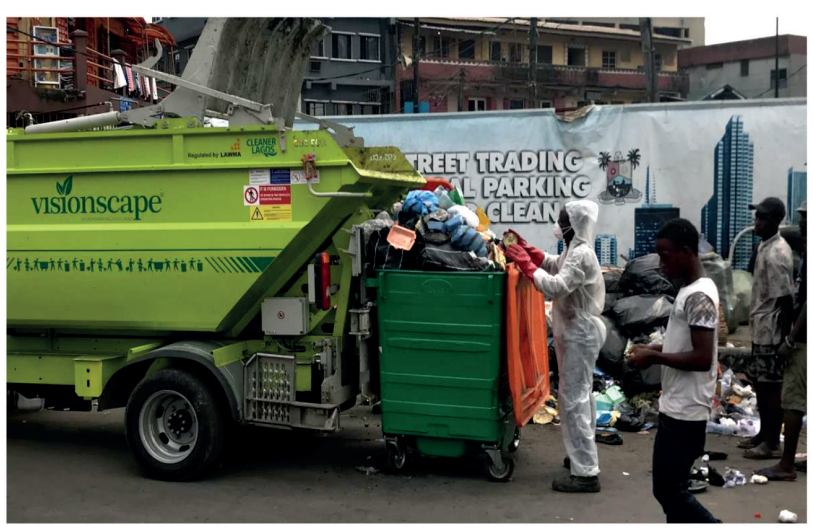

Source: (b) www.saharareporters.com

June 20I9 reported that the Lagos state government signed an executive order to facilitate the building of a resource center at Olusosun dumpsite for training and retraining of youths, scavengers on waste sorting, recovery and conversion to wealth. Also, the Also, the Daily Trust (2016), Abuja Environmental Protection Board (AEPB) reported that 2016 would witness a departure from the traditional system of waste storage to an integrated solid waste management system in the Federal Capital Territory (FCT), Nigeria. AEPB director, reported that with the new system, waste will be separated at source with the provision of two coloured waste bins, green and blue. He further stated that the green bin will be used to store garbage such as food remnants while the blue bin will be used for the collection and storage of recyclable materials such as glass, plastics, pet bottles, cardboard etc." The AEPB and Japan International Cooperation Agency (JICA) are in collaboration on a pilot project on a semi-aerobic Landfill as a pilot on disposal. Also, the introduction of material recovery facility at transfer stations for recycling at the on-going construction of transfer station at (Apo, Mpape and Kubwa) Abuja, Nigeria.

Figure 2. Scavengers in Nigeria (a) \& (b)

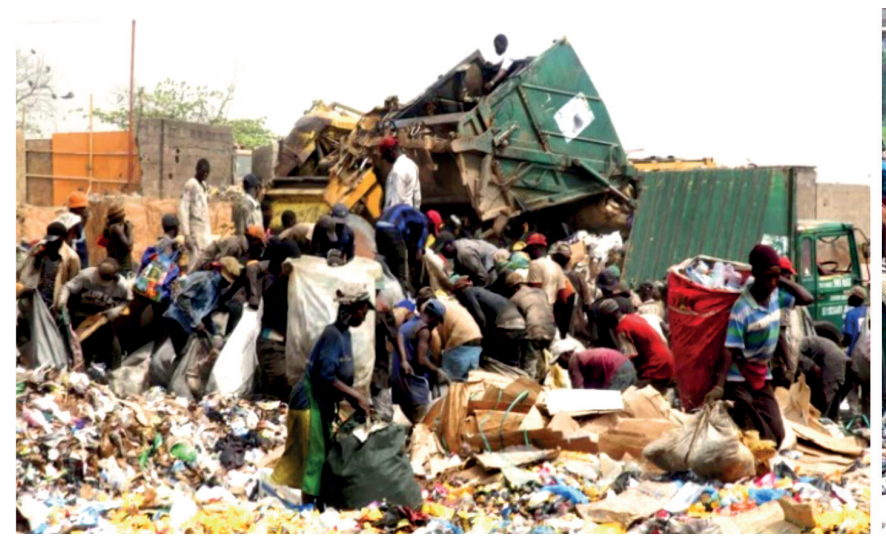

Source: (a) https://guardian.ng

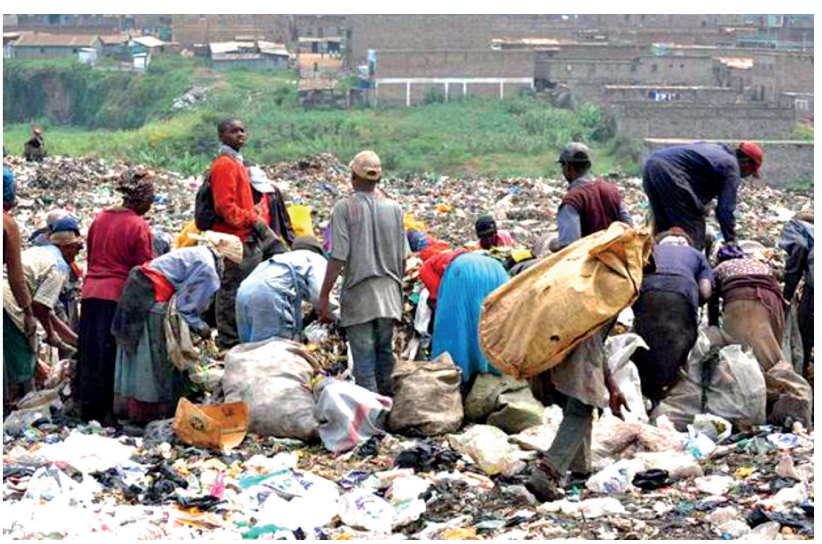

Source: (b) www.environewsnigeria.com 


\subsection{WASTE-TO-ENERGY (WTE)}

Fossil fuel has been the main source of energy in most countries over the years. The continued concerns over energy prices, increasing population and climate change issues has led the drive towards a need for alternative and new energy sources (Amoo \& Fagbenle, 20I3). Waste-toEnergy (WTE) technologies can be described as any waste treatment process that creates energy in the form of electricity, heat or transport fuels (e.g. diesel) from a waste source. The WTE industry has proven itself to be an environmentally friendly solution to the disposal of MSW and the production of energy (Kumar, Subbaiah \& Prasada Rao, 20IO). WTE technologies can convert the energy content of different types of waste into various forms of valuable energy hence electric power is produced and distributed through local and national grid systems (WEC, 2013). The design and optimization of solid waste management technologies and practices aims at maximizing the yield of valuable products from waste, as well as minimizing the environmental effects (Johannessen \& Boyer, 1999). Waste-to-Energy technologies has the capability of converting the energy content of different types of waste into various forms of valuable energy, hence electric power is produced and distributed through local and national grid systems (WEC, 2013). According to Suberu, Mokhtar \& Bashir, (20I2), thermo-chemical conversion is preferably used due to its ability to ensure that the contribution of both biodegradable and non-biodegradable components of the waste are used for the energy output. Waste combustion according to Voelker (2000) provides integrated solution to the problems of modern era "by recovering otherwise lost energy, thereby reducing our use of precious natural resources, cutting down our emissions of greenhouse gases, saving valuable land that would otherwise be destined to become landfill and recovering land once scarified to product of consumerism. WTE technology, according to Lauber (2005), is a robust for minimal environmental risk which has been proven in practice over several decades. In a way to reduce emissions of GHG from WTE facilities, several technologies have been developed to enhance the process of energy generation from MSW cleaner, more economical and sustainable. WTE facilities currently produce clean, renewable and reliable energy through combustion of waste in specially designed power plants equipped with the most pollution control equipment to clean emissions. The USEPA in its report affirms that MSW has a potential of generating clean energy from a sustainable perspective: waste reduction, recycles the recyclables, and GHG emission reduction in the environment (Amoo \& Fagbenle, 2013). Research has shown and demonstrated that WTE plant does supply power 24 hours daily throughout the year. However, there is a constant need for trash disposal.

\subsection{INCINERATION WITH ENERGY RECOVERY}

This process can simply be described as the combustion of MSW with energy recovery. It is basically the combustion of unprepared (raw or residual) MSW. However, the combustion process for the purpose of energy recovery require that the moisture content in the MSW is less than $50 \%$ otherwise the MSW is likely to require a pre-drying process (He, Giannis \& Wang, 20I3). In this process (see fig. 3), MSW is delivered through waste collection vehicles and feed into a bunker where it is thoroughly mixed. The mixing is required to blend the waste to ensure that the energy output to the combustion chamber is consistent. The combustion in this process requires enough oxygen to oxidize fuel (MSW). Energy recovery from incineration of MSW utilizes the combustion heat through a boiler generation steam. The combustion temperatures are in excess of about $850 \circ \mathrm{O}$ such that the MSW is converted into $\mathrm{CO}_{2}$ and water. About $80 \%$ of the available energy in the waste stream can be retrieved in the boiler to produce steam and the steam is used for power generation through a steam turbine (DEFRA, 20I3). The non-combustible materials in this process are referred to as bottom ash. Combustion of MSW results in the emission of $\mathrm{CO}_{2}$ and other greenhouse gases. Nonetheless, studies have shown that the more efficient the energy generation process, the lower the carbon emission per unit energy produced. Consequently, there are policies and guidelines recommended for the use of local energy sources like incineration of MSW with energy recovery and $\mathrm{CO}_{2}$ mitigation (Korobitsyn, Jellema \& Hirs, 1999). Some European countries like Denmark, Portugal, Germany among others use incineration to shrink and recover energy from large quantity of their disposed MSW. The Industrial Emission Directive (IED) in 2oro, stated its goal as to 
Figure 3. Incineration of MSW for Power Generation

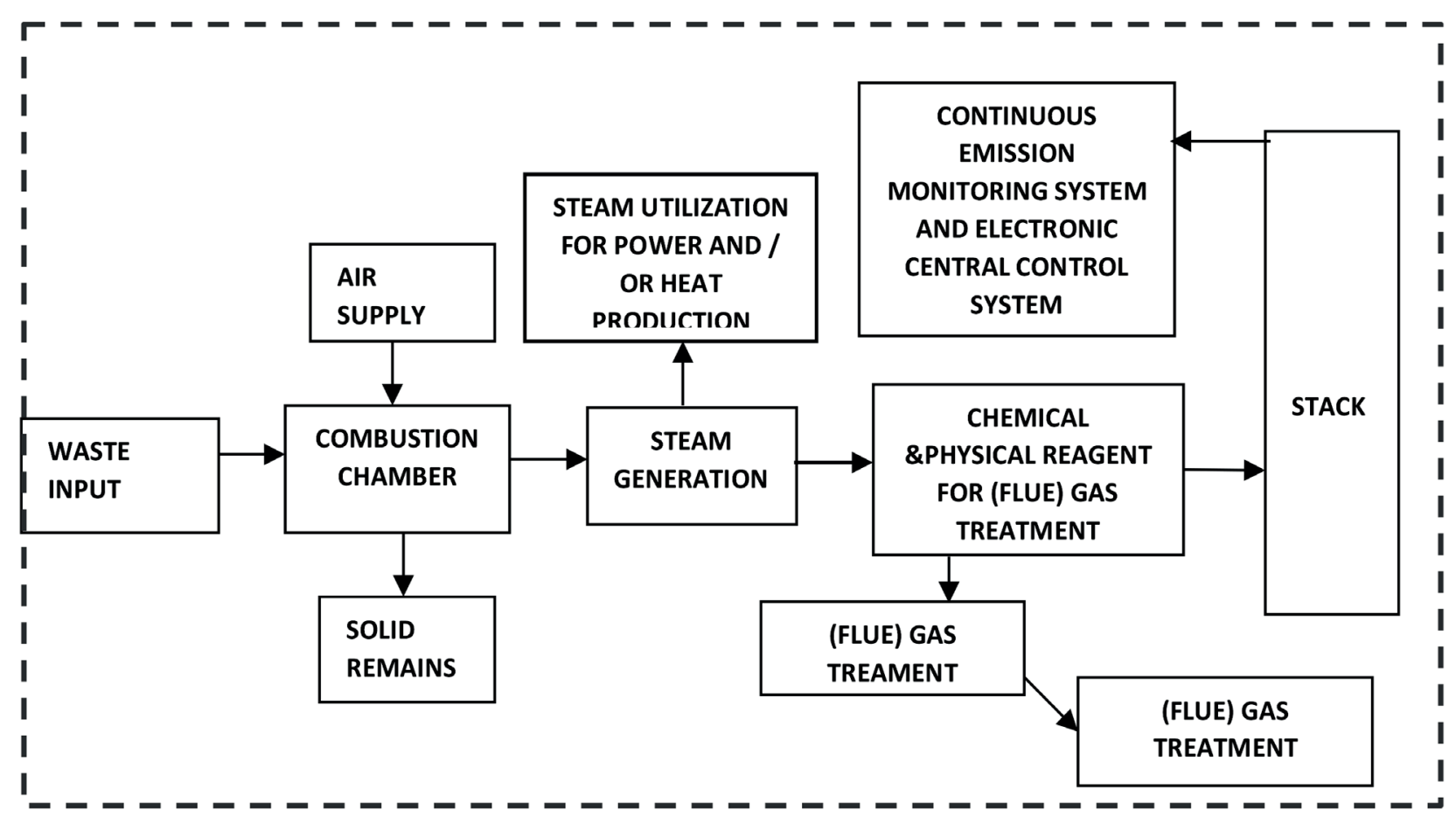

Source: www.intechopen.com

“reduce emissions into air, soil, water and land, and to prevent the generation of waste in order achieve a high level of protection of the environment taken as a whole". Hence, the combustion conditions from any incineration plant is required to ensure complete burnout of the feed in waste and emission limits into the atmosphere are set to minimize any environmental and health impact. The incineration with energy recovery is advantageous according to Tchobanoglous \& Kreith (2002). They revealed in their research that the advantages of incineration includes: the immediate reduction of volume and weight of waste without long time of residence in the environment; incineration exercise can be carried out on site (landfill/dumpsite); emissions can be controlled to the minimum; and the ash content are sterile. Plastics have the highest LHV content over all other constituents of the MSW (Nordi, Palacios-Bereche R, Gallego \& Nebra 20I7). Hence, it is the most desirable constituent of the MSW in terms of incineration with energy recovery.

\subsection{GLOBAL OVERVIEW OF WASTE PLASTICS, AND WASTE PLASTICS IN NIGERIAN}

Plastics are found in all major MSW categories, containers and packaging plastics (bags, sacks, and wraps, other packaging, other containers, and soft drink, milk, and water containers) represent the highest tonnage (USEPA, 2002). In 2015, Jambeck et al. revealed that China produced the largest quantity of plastic annually, at nearly 60 million tons, followed by the United States at 38 million, Germany at I4.5 million, Nigeria at 5.96 million tons, and India at 4.49 million tons (see fig. 4). According to (Jambeck et al., 2015), developed countries, including most of Europe, North America, Japan among others have very effective waste management infrastructure and systems which ensures that discarded plastic wastes are well managed and stored in secure, closed landfills. However, they further stated that, inadequately disposed waste can be high; across many developing countries in South Asia and Sub-Saharan Africa, between 80-90 percent of plastic waste (see fig. 5) is inadequately disposed of, and therefore at risk of polluting rivers and oceans.

According to UNEP (2005) heavier dependence on the use of plastic based packaging material in developing countries may result in increased incidences of littering the outcome of which could lead to the pollution of the environment (including water bodies) and blockage of drainages. In recent times, there have been great concern on the impact of plastics on the environment as it aids urban flood because of its disposal into the drainage systems. For instance, (Aderoju, Guerner Dias \& Anwasia, 2or6) revealed that indiscriminate dumping of waste in Lokoja, Nigeria has contributed to the 
Figure 4. Global plastic waste generation per annum

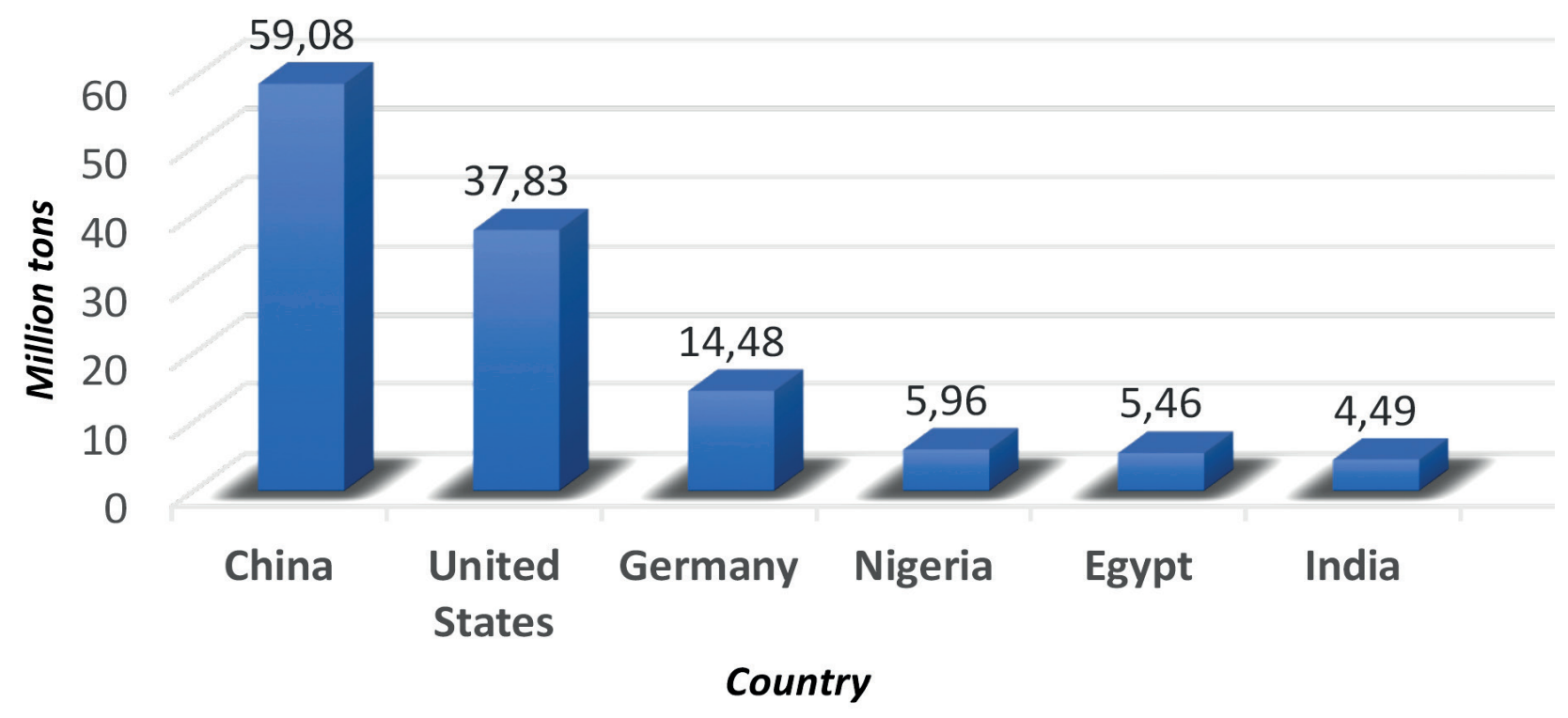

Source: Ritchie \& Roser (2018)

Figure 5. Inadequately managed plastics.

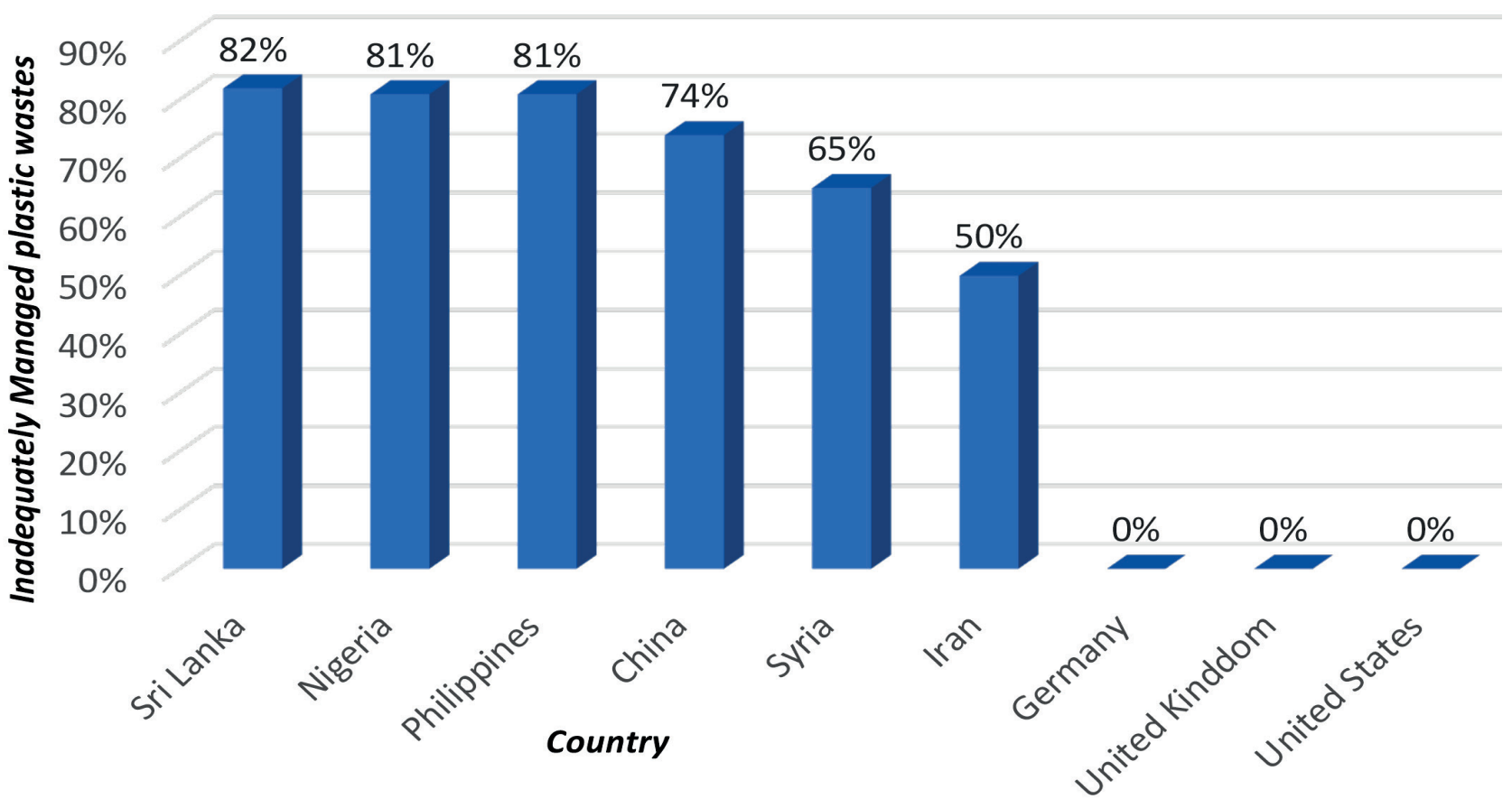

Source: Jambeck et al. (2015)

constant flash flood events during the rainy season. Again, microplastics have been reported ingested by sea animals which is likely to be consumed by humans eventually. (Revel, Châtel \& Mouneyrac, 20I8) stated the several ways by which plastic particles can be ingested: orally through water, consumption of marine products which contain microplastics, and inhalation of particles in the air.
In Nigeria, the situation of waste plastics in the environment has been an adversity to the authorities and the populace. Uncontrolled consumerism, unregulated production and circulation of the products, and improper disposal and management of the final waste output have been identified as major contributing factors to excessive plastics (post-consumer PET bottles) in the major cities 
Figure 6. (a) Littered street with plastics; (b) River pollution with plastics

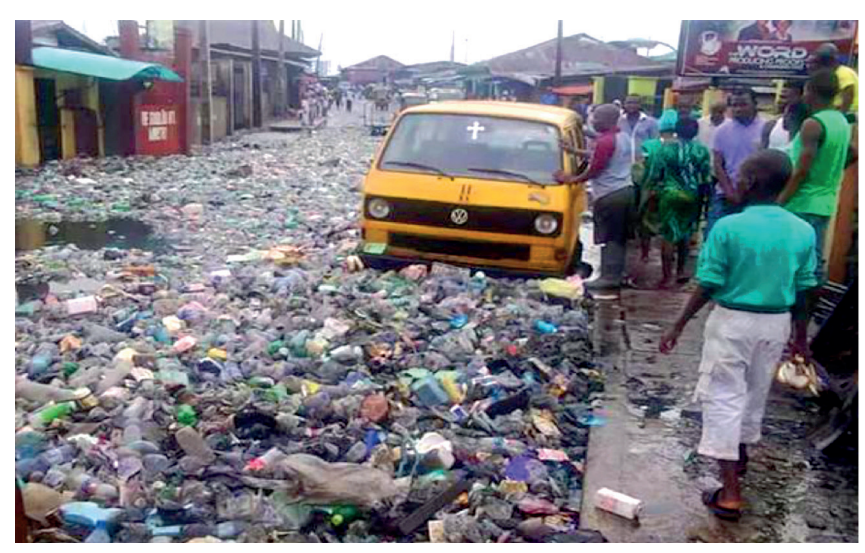

(a) www.punching.com

in Nigeria (Abdulkarim \& Abiodun, 20I2). Floods wreak havoc seasonally on Nigeria, especially in populated metropolitan cities where plastic bottles, plastic bags (popularly known as polythene bags) and other waste materials crammed drainage channels, thereby hindering free flow of water whenever it rains (Punch Newspaper, 2018). Also, (Aderoju, Guerner Dias, Ekweozoh \& Offiong, 20Ig) revealed that poor waste management practices and unethical behavior of the people upon the MSW disposal in Nigeria have led to littered street, and inland waterways pollution with excess plastic waste (see fig. 6a and 6b).

Nonetheless, few small medium entrepreneurs (SMEs) have set up plastic recycling projects and only specified plastics such as polyethylene terephthalate (PET) among others that are not contaminated are usually accepted otherwise it is rejected. Therefore, this is an implication that just a small percentage of plastics are recycled in Nigeria, even so, a greater quantity of these plastics ends up as garbage in the streets, drains, and watercourse / shores across the country. The importance of managing plastic waste in Nigeria should be emphasized especially with the rapid population growth and the unregulated production and use of plastic products for packaging.

\section{METHODOLOGY}

The approach employed in this study was establishing a sustainable strategy that is likely to reduce waste plastics from the Nigeria communities. The study tends to exploit the concept of MSW segregation from source with the focus on waste plastics to be collected at garbage collection points for the purpose of electric power generation. The characterization of MSW in Abuja, Nigeria was

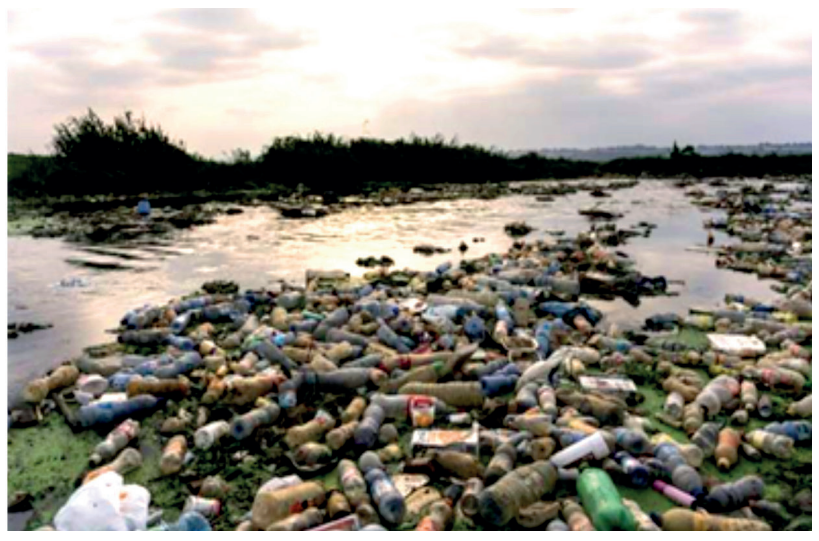

(b) https://fote.org.ng

adapted from Aderoju \& Guerner Dias (2018). The choice of Abuja was a preferable option as it is the nation's capital and its inhabitants fairly represent all the ethnic groups and their culture in Nigeria. The study tends to employ the incineration of waste plastics for electrical power production in Nigeria since the Nigeria power sector is deficient in providing electricity for the populace. Furthermore, this empirical study performed proximate and ultimate analyses on the waste plastics in the MSW stream to estimate the higher heat value (HHV) and lower heat value (LHV), and it went on to determine the power generation potential (PGP) of the waste plastics in Nigeria.

\section{I STUDY AREA}

Nigeria is a country located in the western part of the African continent which lies between the latitudes $50 \mathrm{~N}$ and $150 \mathrm{~N}$ and longitudes $50 \mathrm{E}$ and 150E (see fig.7) and a landmass of approximately 924,0ookm2. Nigeria is a federal republic in West Africa, bordering Niger in the north, Chad in the northeast, Cameroon in the east, and Benin in the west. Its coast in the south is located on the Gulf of Guinea in the Atlantic Ocean. The federation comprises 36 states and the Federal Capital Territory, with its capital city, Abuja. Nigeria is blessed with many natural resources like crude oil, natural gas, limestone, gold, among others. Also, Nigeria has an immense potential of hydropower generation because of two great rivers (Rivers Niger and Benue) entering from the Northeast and Northwest, and with an access to $840 \mathrm{~km}$ coastline in the Southern part of the country (Adebayo, 20I4). The southern part of Nigeria lies on the coastline hence its tidal power potential can be utilized for power generation. However, 


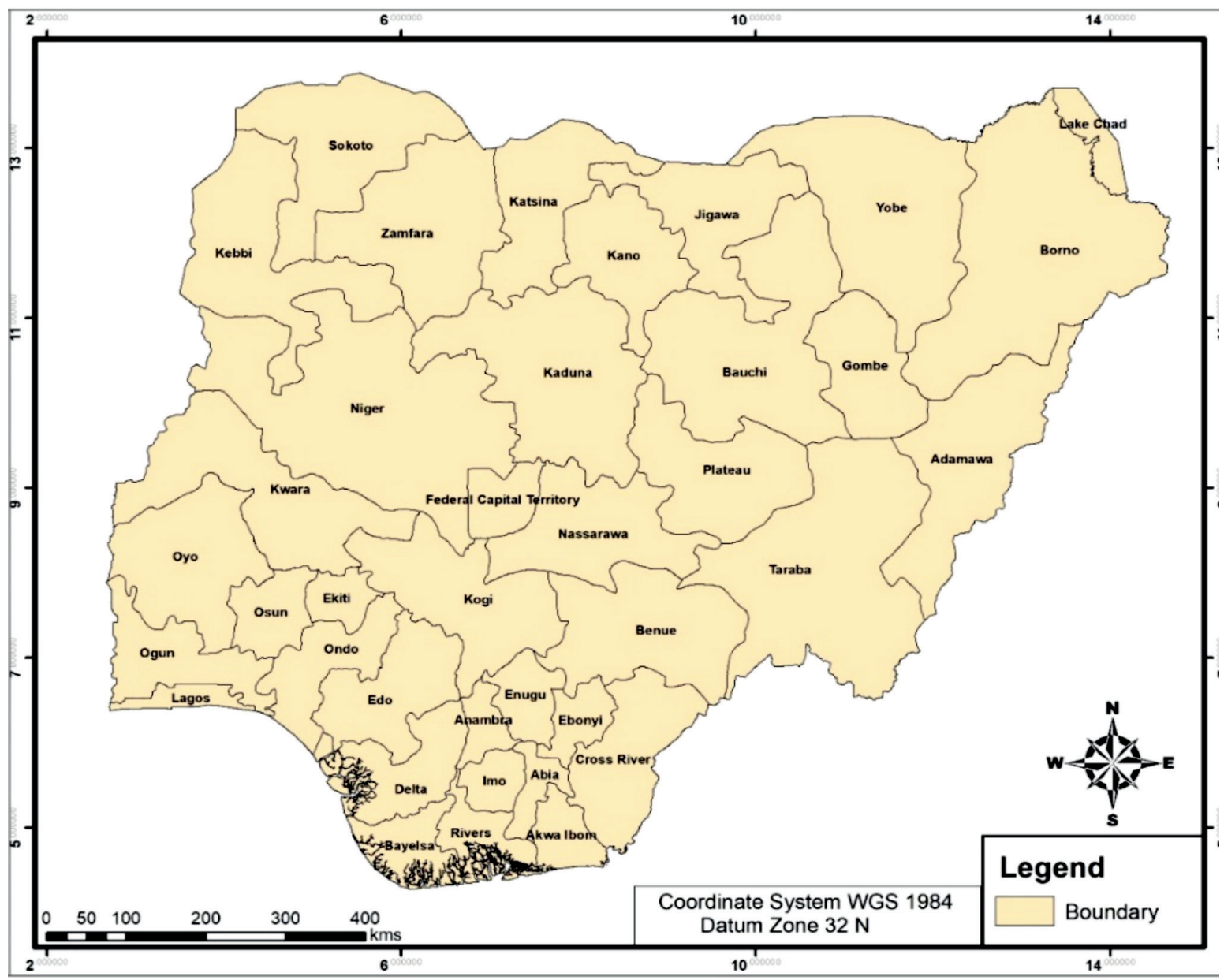

the northern part of Nigeria is close to the Sahara region, hence it tends to experience a lot of sunlight and medium winds for a considerable electrical power generation.

\subsection{WASTE PLASTICS COLLECTION STRATEGY}

The creation of plastic collection points $(\mathrm{PCP})$ in specified but suitable places whereby only waste plastics are collected in closed or monitored bins/ facility to prevent littering. Active participation plays a very important role in the collection of waste plastics from the environment. The two methods for the collection of waste plastics in the environment are the incentive-based approach and the Extended Producer Responsibility (EPR) approach (see fig. 8). These two methods will enhance the responsibility of the waste plastics collection by the combined effort of principal actors in the waste management sector. The principal actors, in this case, are the manufacturer of plastic packaging products, the consumers, and the collection firms/individuals (scavengers).

\subsection{WASTE CHARACTERIZATION}

This study adapts the characterization of the MSW in Aderoju \& Guerner Dias (2018). The American Standard Test Method (ASTM D 5231-92) was

Figure 8. Waste Plastics Collection Strategy

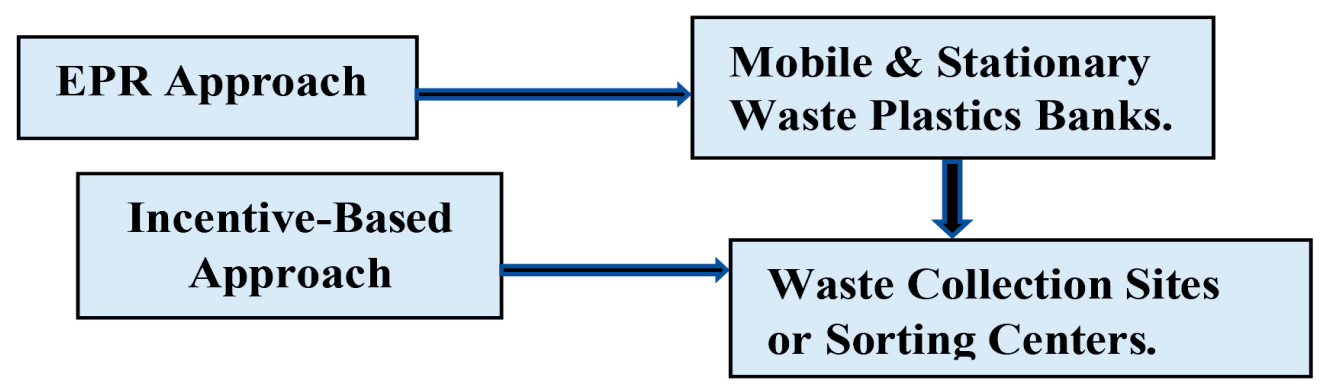


used for the characterization of the MSW at the major landfills (Gosa; Karshi; Kubwa; and Dutse) in Abuja during the wet season and dry season. The characterization of these waste streams was carried out in each of the landfills 3 times a week for 4 weeks during the wet and dry seasons of the year. A manual collection of ro $\mathrm{kg}$ of freshly mixed MSW in all the landfills 3 times a week for 4 weeks during the wet and dry seasons of the year. Io $\mathrm{kg}$ of freshly mixed MSW were collected as samples and were thoroughly mixed and weighed with a handheld weighing device after every collection at each of the landfills. Samples were manually sorted into 8 categories, then each category of MSW type is reweighed to determine the composition of MSW in a mix. The physical analysis was done based on weight ratio of different components in the MSW stream. The percentage of samples composition were categorized into 8 different components which are: food waste/organic; textile; paper; plastics; glass/ ceramics; metal; rubber: and other waste materials. The category of other waste includes tiny stones and grit, used batteries, and composite materials. The mean weight ratio for each of the landfills for both dry and wet seasons was estimated as shown in fig. 9. Furthermore, the mean \% waste plastics present in the results of the characterization exercise at each landfill was extracted and it was labeled SDUT, SKUB, SKAR, SGOS respectively see table I.

\subsection{PROXIMATE ANALYSIS}

Proximate analysis was used to evaluate the moisture, volatile matter, fixed carbon and ash content of the waste plastic samples. A subsample of Iog was drawn from each of mixed samples of waste plastics from each of the landfills (SDUT, SKUB, SKAR, SGOS) in Abuja. Each of the subsamples of waste plastics (WPDUT, WPKUB, WPKAR, WPGOS) were mixed and shredded and formed into pellets and flakes. Another $5 \mathrm{~g}$ was drawn again from each of the subsamples and it was mixed together in a single bowl and it amounted to $20 \mathrm{~g}$ which is a fair representation of the waste plastics from the 4 landfills. This new mixed sample containing waste plastics from the 4 landfill is referred to as sample $Z$. The sample $\mathrm{Z}$ was placed into 2 petri dishes and was heated in oven for I hr at ${ }_{1050 C}$ to determine the moisture content and dry mass of sample $\mathrm{Z}$. For an additional loss of weight, $25 \%$ of the dry mass of the sample $\mathrm{Z}$ was placed in the crucible after the initial weight of the crucible had been obtained, and later reweighed before it was placed into the SXL-I20ooC benchtop Muffle furnace on ignition at $9500 \mathrm{C}$ for $30 \mathrm{~min}$ to determine the \% volatile matter (dry basis) and \% ash content. The Eq. (I), (2) and (3) was used for the calculations in proximate analysis was adapted from Kuleape et al. (20I4).

$$
\begin{aligned}
& M=\{\{w-d\} 100\} / w \\
& \text { Where: } M=\text { wet-mass moisture content, \%; } \\
& \mathrm{w}(\mathrm{kg})=\text { initial mass of WP subsample; } \\
& \mathrm{d}(\mathrm{kg})=\text { mass of subsample after drying. } \\
& \mathrm{Vm}=\{\{\mathrm{d} 1-\mathrm{w} 1\} 100\} / \mathrm{d} 1 \\
& \text { Ash }=\{\mathrm{w} 1 * 100\} / \mathrm{d} 1
\end{aligned}
$$

Where; $\mathrm{Vm}=\%$ volatile (dry basis); Ash= \% ash (dry basis);

d1= weight of dry sample Z; w1 = weight of residue after ignition.

Figure 9. Abuja landfill Composition

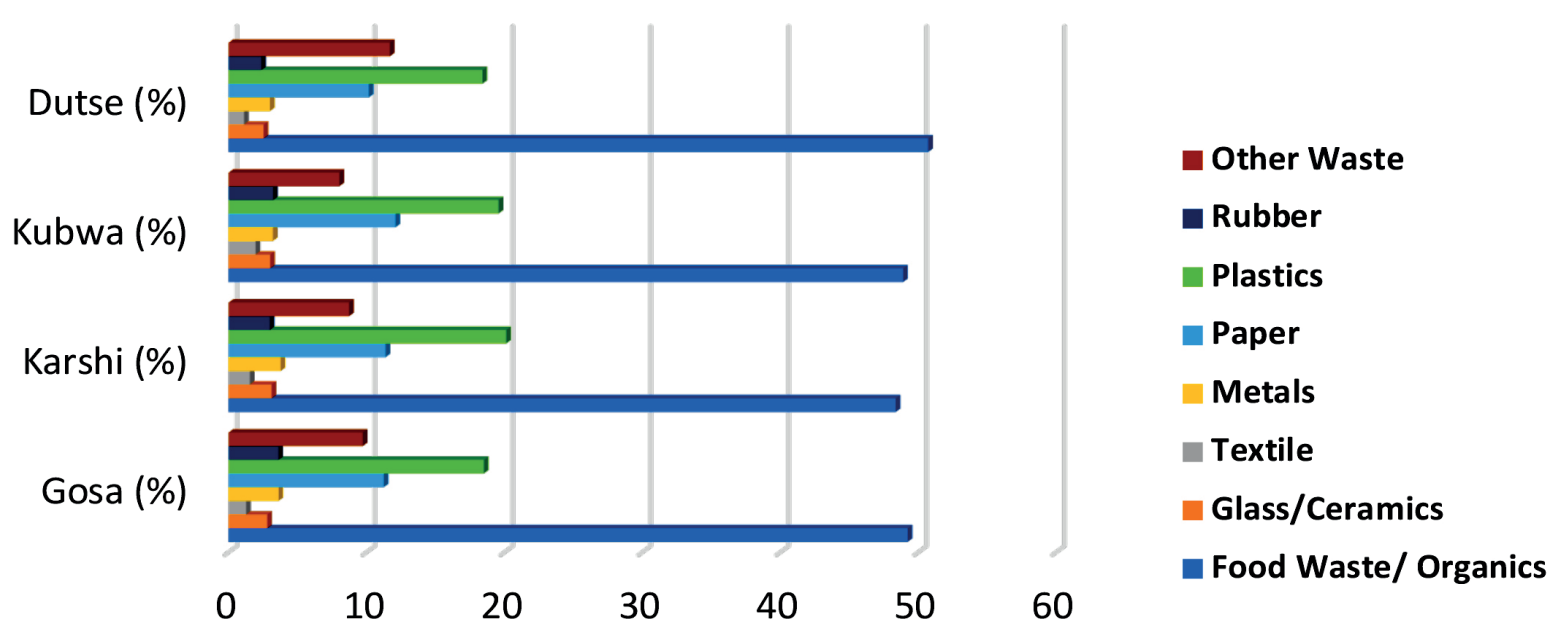




\subsection{ULTIMATE ANALYSIS}

The ultimate analysis was used to estimate the elemental content which includes; carbon, hydrogen, oxygen, nitrogen, sulphur and ash (C, $\mathrm{H}, \mathrm{O}, \mathrm{N}, \mathrm{S}$ ) present in the sample under investigation. However, plastics only contain carbon, hydrogen and oxygen. Provided the dry mass of the sample is determined, the elemental contents like carbon, hydrogen, oxygen and the ash content for waste sample can be determined using the standard table of ultimate analysis of combustible waste in (Tchobanoglaus, Theisen \& Vigil, I993). The elemental content can be estimated by the expression (see Eq. 4);

$$
\begin{aligned}
& \mathrm{Ec}(\mathrm{kg})=\{\mathrm{d} * \mathrm{Ev}\} / 100 \\
& \text { Where; Ec = Elemental Content }(\mathrm{kg}) ; \\
& \mathrm{d}=\text { Dry mass; } \\
& \mathrm{Ev}=\text { Element value (use standard elemental table) }
\end{aligned}
$$

The element content values in these waste plastics sample $Z$ was obtained using the standard table and dry mass of the sample. Moreover, the elemental contents for the sample $Z$ was computed and it was substituted into the modified Dulong equation (Tchobanoglous, Theisen \& Vigil, I993) to determine the energy content (HHV) of the waste plastics and it is expressed in Eq. (5) as;

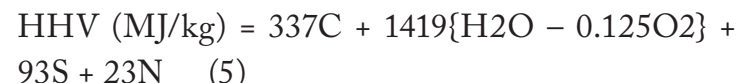

Where: $\mathrm{C}=$ Carbon (\%); $\mathrm{H}=$ Hydrogen (\%);

$\mathrm{O}=$ Oxygen (\%); $\mathrm{S}=$ Sulphur (\%);

$\mathrm{N}=$ Nitrogen (\%).

\subsection{ENERGY OUTPUT ESTIMATION FROM WASTE PLASTICS}

The calorific value is classified into the Higher Heat Value (HHV) and Lower Heat Value (LHV). In a study by (Franjo, Ledo, Rodriguez \& Nunez, I992), the HHV was defined as the quantity of heat generated by a complete combustion of a unit mass of sample in air or oxygen, such that the product of combustion cooled down to the room temperature and remains in liquid form. Again, they also described the LHV as the net heat produced when a unit mass of the sample is completely burnt in air or oxygen, such that the product of combustion can escape as steam. The LHV of the waste plastics subsample was calculated using eqn (6) as it was done in (Prasada Rao, Venkata \& Sudhir, 20Io) as;
Where: LHV = Lower Heat Value;

$\mathrm{HHV}=$ Higher Calorific Value;

LHS = Latent Heat of Steam which is $587(\mathrm{kcal} / \mathrm{kg})$; $\mathrm{H}=$ Hydrogen (\%).

\subsection{POWER GENERATION POTENTIAL FROM WASTE} PLASTICS

Reported that the amount of energy recovered from MSW based on different conversion methods is a function of its calorific value and organic content(Tsunatu, Tickson, San \& Namo, 20I5). In this context, waste plastics is considered as the fuel to be utilized for combustion in wasteto-energy plants, and with the heat from the fire to make steam (LHV) for electric power generation. Therefore, the Energy Recovery Potential (Erp) as expressed in Eq. (7) is simply the amount of energy that can produce electric power supply or heat system for an hour. However, the power generation potential is the amount of energy that can produce electric power supply or heat system for 24 hours, and it is expressed Eq. (8) as:

$$
\begin{aligned}
& \operatorname{Erp}(\mathrm{kWh})=\mathrm{LHV}^{*} \mathrm{~W}^{*}\{1000 / 860\} * \beta(7) \\
& \text { Where; Erp }(\mathrm{kWh})=\text { energy recovery potential of } \\
& \text { waste plastics; } \\
& \mathrm{LHV}=\text { Lower Heat Value; } \mathrm{W}=\text { Weight of plastics } \\
& \text { (tons); } \\
& \beta=\text { Conversion Efficiency is between } 22 \%-28 \% \\
& \text { (IEA, 2007). }
\end{aligned}
$$

The power generation potential (PGP) as it is in Eq. 8; it was further expanded in Eq. 9:

$$
\begin{aligned}
& \text { PGP }(k W)=\text { Erp } / 24 \\
& \text { PGP }=\mathrm{LHV}^{*} \mathrm{Wt}^{*} 0.04845^{*} \beta(9)
\end{aligned}
$$

\section{RESULTS AND DISCUSSION}

In this section, results of the MSW characterization during the wet and dry season in Abuja, Nigeria (see table I). Also, the results of proximate and ultimate analyses are shown in table 2 and table 4 respectively. Others includes the mathematical estimation of the calorific values ( $\mathrm{HHV}$ and LHV), and the power generation potential of the waste plastics in Abuja and Nigeria at large was equally carried out. The discussion of the results was explicitly explained. 
Table 1. the mean \% waste plastics characterization in Abuja, Nigeria

\begin{tabular}{|c|c|c|c|}
\hline SAMPLE NAME & $\begin{array}{c}\text { WASTE PLASTICS DRY } \\
\text { SEASON } \%\end{array}$ & $\begin{array}{c}\text { WASTE PLASTICS WET } \\
\text { SEASON } \%\end{array}$ & $\begin{array}{c}\text { WASTE PLASTICS MEAN } \\
(\%)\end{array}$ \\
\hline SDUT & $\mathrm{I} 7 \cdot 77$ & 19.05 & I8.4I \\
\hline SKUB & 19.09 & 20.05 & I9.57 \\
\hline SKAR & I9.90 & $\mathrm{I} 8.42$ & I8.5I \\
\hline SGOS & I8.6o & I9.09 & I8.5I \\
\hline
\end{tabular}

Table 2. Waste plastics proximate analysis result

\begin{tabular}{|c|c|c|c|c|}
\hline WASTE TYPE & WET MASS (KG) & DRY MASS (KG) & $\begin{array}{c}\text { MOISTURE } \\
\text { CONTENT (\%) }\end{array}$ & $\begin{array}{c}\text { MOISTURE } \\
\text { CONTENT (G) }\end{array}$ \\
\hline Plastics & 0.02 & 0.01949 & 2.56 & $0.005 \mathrm{II}$ \\
\hline
\end{tabular}

Table 3. Elemental Composition \% for (dry basis) waste plastics; Source: Tchobanoglous et al. (1993)

\begin{tabular}{c|c|c|c|c|c|}
\hline WASTE TYPE & CARBON (\%) & HYDROGEN (\%) & OXYGEN (\%) & NITROGEN (\%) & SULPHUR (\%) \\
\hline Plastics & 60 & 7.2 & 22.8 & NIL & NIL \\
\hline
\end{tabular}

Table 4. Ultimate Analysis result of waste plastics sample for Abuja, Nigeria

\begin{tabular}{|c|c|c|c|c|c|c|c|}
\hline WASTE TYPE & $\begin{array}{c}\text { WET } \\
\text { MASS(G) }\end{array}$ & DRY MASS(G) & $\begin{array}{c}\text { MOISTURE } \\
\operatorname{CONTENT}(\mathrm{G})\end{array}$ & $\mathrm{C}(\mathrm{G})$ & $\mathrm{H}(\mathrm{G})$ & $\mathrm{O}(\mathrm{G})$ & $\operatorname{ASH}(G)$ \\
\hline Plastics & 20.00 & I9.488 & $0.5^{12}$ & II. 693 & $\mathrm{I} .4 \mathrm{O}$ & 4.443 & I.949 \\
\hline
\end{tabular}

\section{I.I CALCULATING FOR HHV AND LHV}

For HHV and LHV, the estimated $(\mathrm{C}, \mathrm{H}, \mathrm{O})$ data in table 4 shows the total elemental content in a waste plastics sample for Abuja. Given; $\mathrm{C}=$ $0.01169 \mathrm{~kg} ; \mathrm{H}=0.001403 \mathrm{~kg} ; \mathrm{O}=0.004443 \mathrm{~kg}$; By substituting the $(\mathrm{C}, \mathrm{H}, \mathrm{O}, \mathrm{N}, \mathrm{S})$ values in the modified Dulong equation (See Eq. 5).

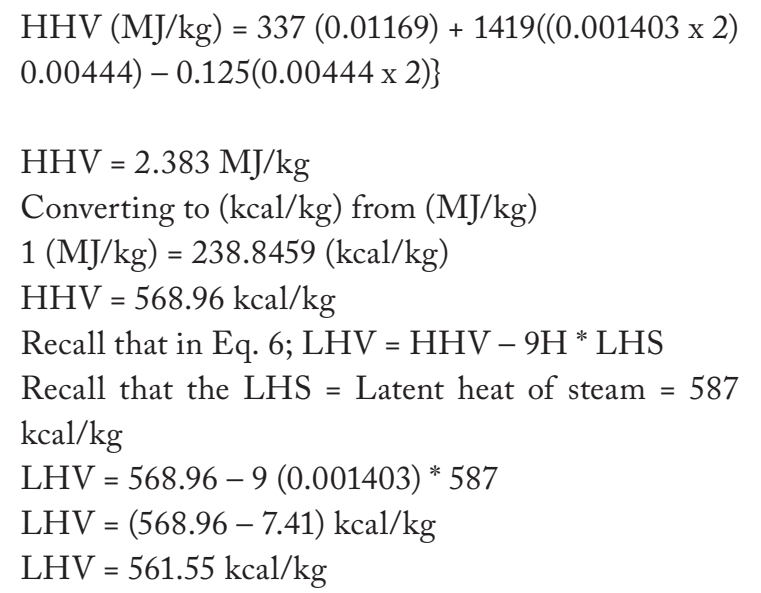

4.I.2 ESTIMATION OF THE POWER GENERATION POTENTIAL (PGP)

Recall that from Eq. (7,8 \& 9);

$\operatorname{Erp}(\mathrm{kWh})=\mathrm{LHV}^{*} \mathrm{~W}^{*}\{1000 / 860\} * \beta$

$\operatorname{PGP}(\mathrm{kW})=\operatorname{Erp} / 24$

$\mathrm{PGP}=\mathrm{LHV}^{*} \mathrm{Wt}^{*} 0.04845^{*} \beta$

Using Ioo tons of waste plastics,

$=56 \mathrm{I} .55 *$ IOO $* 0.04845 * 0.22$

$=598.56 \mathrm{~kW}$

$=0.6 \mathrm{MW}$

Recall that from fig. 4, that the annual plastic production in Nigeria is about 5.96 million tons. In addition, according to Jambeck et al. (2015) see fig. $5,81 \%$ of produce plastics in Nigeria are inadequately managed and it is assumed that these mismanaged plastics finds its way into the environment. Therefore, $8 \mathrm{I} \%$ of 5.96 million tons was estimated to be 4.83 million tons of waste plastics. 
Using 4.83 million tons of waste plastics;

$=561.55 * 4.83 \times 106 * 0.04845 * 0.22$

$=2891026 \mathrm{r} .8 \mathrm{okW}$.

$=28,9 \mathrm{roMW}$.

\subsection{DISCUSSION}

In many Nigeria cities, the situation of poorly managed MSW has led to serious environmental consequences such as flood disasters, health risk and financial liabilities. The components of MSW in Nigeria basically includes food waste/organics, plastics, paper, metals, rubber, textile, and other wastes (grits, used batteries, and other composite materials). However, plastic which is otherwise referred to as waste plastics in this study has been a threat to mankind and the world at large. The situation of excessive waste plastics in the Nigeria environment was confirmed by Jambeck et al. (2015) that over $81 \%$ of produce plastics in Nigeria are inadequately mismanaged. Hence, this study intends to reduce the incoming and backlogs of waste plastics in Nigeria by utilizing it as fuel in a WTE plant for electric power generation. The study identifies the need for the collection of waste plastics from the environment and therefore devised two methods for its collection.

The two methods devised for the collection includes; the incentive-based approach and the Extended Producer Responsibility (EPR). The incentive-based approached require the use incentive (money or gift) to encourage the segregation of MSW from the source. This act is likely to promote sorting out waste plastics which will eventually become a daily practice to the people if well conceded. On the other hand, a big business to scavengers whose livelihood depends on selling recovered materials from MSW. The EPR approach is a little different because it requires the legislative arm of the government to enact a law that mandates packaging companies especially those that utilize plastics in their production and packaging to take responsibility for the removal of the waste products that emanate from their products at production and distribution levels. This law will prompt packaging companies to employ small enterprise to help them recover the waste from their products in the environment. This can be done by positioning coloured bins with waste type specification in recreational places, business and residential districts, religious homes, schools (elementary, secondary and tertiary), marketplaces among others for the recovery of waste plastics and other MSW category. The collected waste plastics are transported to central collection sites where it can be accessed by energy recovery and recycling companies.

From the proximate analysis experiment, tables 2 show the result obtained using the waste plastics sample $Z$ which represents Abuja, Nigeria. However, it was deduced that the moisture content played a little role in the estimation of the amount of Carbon; Hydrogen, Oxygen of waste plastics to determine the energy output. It was clear that the moisture content in waste plastics in Nigeria is $2.56 \%$ despite being kept in open bins or dumped in open fields. The derived elemental composition $\%$ (see table 3) using experimental carbon content and ratios of elements given by Tchobanoglous et al, (1993) was used to obtain the higher calorific value $(\mathrm{HHV})$ for waste plastics in Abuja. The elemental composition \% was computed with the dry mass of the waste plastics to obtain the actual mass of the elemental composition in the waste plastic (see table 4). The results of these elemental composition in mass was inputted in the modified Dulong formula to estimate the HHV. Using Eq. 5, the values of $\mathrm{HHV}$ calculated was 568.96 $\mathrm{kcal} / \mathrm{kg}$. In addition, it is vital that for a feasible energy output for power generation, the product of combustion is in form of steam which represents the LHV. Therefore, the LHV for the waste plastics calculated using Eq. 6 was $561.55 \mathrm{kcal} / \mathrm{kg}$.

In order to obtain the PGP of waste plastics, the Eq. 9 was used and it is important to have variables such as LHV, to be calculated; conversion efficiency $(\mathbb{\nabla})$, which is a constant variable which varies from $22 \%-28 \%$ (IEA, 2007); and $\mathrm{Wt}$, which was the weight of the waste plastics utilized. The study considered the lowest conversion efficiency rate of $22 \%$ due to the efficiency of the waste plastics used as fuel, and the type of WTE plant employed. For this study, roo tons of waste plastics was initially used for the estimation and the result of the PGP was 0.6MW. Recall that in fig. 5, Jambeck et al. (2015) reported that $81 \%$ of produce plastics in Nigeria are inadequately managed and it is assumed that these mismanaged plastics are disposed into the environment. Also, from fig. 4 where it was reported that the annual production of plastics in Nigeria was 5.96 million tons. Therefore, $81 \%$ of 5.96 million tons was estimated to be 4.83 million tons of waste plastics. And it was 
inputted into the Eq. 9 and the result of the PGP was at 28,9 IoMW.

\section{CONCLUSION}

Various methods have been used by different researchers on how to effectively sort and collect waste plastics from environment. This study identifies the use of incentive-based approach for scavengers who sort and gather waste plastics to be sold for their livelihood. Also, the adoption of the EPR policy ensures that manufacturers are responsible for the evacuation of the waste plastics from the environment. The manufacturers in turn employs firms that focused on the use of mobile garbage banks for waste plastics collection from schools and religious homes. Furthermore, the placement of coloured bins at recreational places and other public places to segregate different MSW constituents is another way of effectively collecting waste plastics from the environment. A typical example is the Eco Point concept.

This study revealed that the incineration with energy recovery concept is likely to reduce the backlogs and newly generated waste plastics in the Nigerian environment provided that modern technologies and sound emission control system are put in place. Moreover, the study employed the proximate and ultimate analyses using waste plastics samples obtained from the Abuja landfills. The result of this analysis was used to evaluate the $\mathrm{HHV}$ at $568.96 \mathrm{kcal} / \mathrm{kg}$, and LHV at $56 \mathrm{r} .55 \mathrm{kcal} /$ $\mathrm{kg}$. In addition, the power generation potential (PGP) using Ioo tons of waste plastics in Abuja, Nigeria was estimated to be $0.6 \mathrm{MW}$. Hence, based on the Jambeck et al. (2015), 8r\% of produce plastics in Nigeria are inadequately managed. This study estimated that the PGP of mismanaged plastics in Nigeria to about 29,0ooMW. This will go a long way to complement the poor electricity supply in the country.

Based on the findings of the study, it is imperative to ensure the segregation of plastic materials from MSW mix and its proper disposal is carried out with the intention for electric power supply. Although the practice of separating waste plastics might be complex initially, nevertheless its success depends on the synergy among the stakeholders. It is recommended that the government should invest in capital projects such as WTE through public private partnership (PPP), and attract foreign investors in this sector in order to attain a sustainable economy likewise reduce the burden of waste plastics in the society.

\section{REFERENCES}

Abdulkarim I.A \& Abiodun A.O (2012). A study of problems associated generation and disposal in Kano Metropolis. Academic Research International, Vol. 3, No. 2, pp 56-65.

Adebayo C (2014). "How is 100\% Renewable Energy Possible for Nigeria?" Global Energy Network Institute (GENI). Retrieved from geni.org/global energy; Accessed on the 25/04/19.

Adebola O.O (2006). The Role of Informal Private Sector in Integrated Solid Waste Management (ISWM) in Lagos, Nigeria - A Developing Country. Proceeding of the 21st International Conference on Solid Waste Technology \& Management. Philadelphia P.A, March 26th - 29th.

Aderoju O.M, Guerner Dias A. \& Anwasia B (2016). Ancestral Heritage of Flood plain Residence and Solid Waste Disposal Pattern in Flood Events in Kogi State, Nigeria, Conference Proceedings of the 3rd International Conference on Environmental and Economic Impact on Sustainable Development; in Valencia, Spain; June 8th - 10th. Ecology and The Environment, Vol 203, p 37-48, WIT Press, ISSN 1743-3541 (on-line).

\& Guerner Dias A. (2018). Waste to energy as a complementary energy source in Abuja, Nigeria. WASTES: Solutions, Treatments and Opportunities, Published by Taylors and Francis Group, London, pp 63-68, ISBN 978-1138-19669-8.

Guerner Dias A., Ekweozoh P.C \& Offiong I (2019). A Sustainable approach for Post-consumer PET bottles Recovery and Reduction in Nigeria. Proceedings of the 34th International Conference on Solid Waste Technology and Management, Annapolis, MD, USA; March 31st - April 3rd. Widerner University Press, USA.

, Guerner Dias A. \& Guimaraes R (2015). Building Capacity an Integrated Perception and Attitude towards Municipal Solid Waste Management in Nigeria. WASTES: Solutions, Treatments and Opportunities, Published by Taylors and Francis Group, London, pp 7-12, ISBN 978-1138-02882-1.

Alamgir M, Donald C. Mc, Roehi K. E and Ahsan A. (2005). Integrated management and safe disposal of MSW in least developed Asian countries-A feasibility study, Waste Safe. Khulna University of Engineering and Technology, Asia Pro Eco-Programme of the European Commission.

Amoo, O.M \& Fagbenle, R.L (2013). Renewable Municipal Solid Waste pathways for Energy Generation and Sustainable Development in the Nigerian context. International Journal of Energy and Environmental Engineering, 4/42.

ASTM D 5231-92 (Reapproved 2016). Standard Test Methods for Determination of the Composition of Unprocessed Municipal Waste; ASTM International, 6p, 2016. Available online at: http://www.astm.org/standards/D5231.

Babayemi J.O \& Dauda K.T (2009). Evaluation of Solid Waste Generation, Categories and Disposal options in Developing 
Countries: A case study of Nigeria. J. Appl. Sci. Environ. Management 13(3): 83-88.

Daily Trust (2016). Abuja Environmental Planning Board (AEPB) Plans Integrated Solid Waste Management (ISWM). Retrieved online; https://www.pressreader.com. Accessed on 20/ 03/2019.

DEFRA (2013). Incineration of Municipal Solid Waste; Department for Environment, Food and Rural Affairs. February 2013.www.defra.gov.uk

Franjo C.F, Ledo J.P, Rodriguez A. J.S and Nunez L (1992). Calorific Value of Municipal Solid Waste. Environmental Technology, 13: 11, 1085-1089. DOI: 10, 1080/09593339209385246.

Friends of the Environment (2018). Plastic Wastes von Water. https://fote.org.ng/2018/03/well-phase-plasticbottles-2023-lagos-government/plastic-wastes-on-water/. Accessed on 26/04/2019.

Geyer R, Jambeck J. R \& Law, K. L (2017). Production, use, and fate of all plastics ever made. Science Advances, 3(7), e1700782. Available at: http://advances.sciencemag.org/ content/3/7/e1700782.

He C, Giannis A \& Wang J (2013). Conversion of Sewage sludge to Clean Solid fuel using hydrothermal Carbonzation; Hydrochar fuel Characteristics and Combustion Behavior; Application Energy 2013; 111:257 0266.

How to Start Waste Management Business in Nigeria (2018). Retrieved online from; https://infoguidenigeria.com/wastemanagement-business-nigeria/. Accessed on 15/05/2019.

Huang N. (2012). Industry Insight: Global Plastics Industry. Retrieved online: http://www.businessvibes.com/blog/ industry-insight-global-plastics-industry.

Idowu O, Omirin M, \& Osagie J. (2011). Outsourcing for Sustainable Waste Disposal in Lagos Metropolis: Case study of Agege Local Government, Lagos. Journal of Sustainable Development, 4(6), 116-131.

IEA (2007). Biomass for Power Generation and CHP. IEA Energy Technology Essential, 2007, ETE03, pp 1-4.

Imam A, Mohammed B, Wilson D.C \& Cheeseman R. (2008). Solid waste management in Abuja, Nigeria. Waste Management, 28: 468-472.

Jambeck J. R, Geyer R, Wilcox C, Siegler T. R, Perryman M, Andrady A, Narayan R, \& Law K. L. (2015). Plastic waste inputs from land into the ocean. Science, 347(6223), 768-771. Available at: http://science.sciencemag.org/ content/347/6223/768. Accessed on 20/04/2019.

Johannessen LM \& Boyer G (1999). Observations of Solid Waste Landfills in Developing Countries: Africa. Urban Development Division, Waste Anchor Team, the World Bank. pp 10-12.

Kokalj F \& Samec N (2013). Municipal Solid Waste for Power Production. Advances in Internal Combustion Engines and Fuel Technologies. DOI: 10.5772/55497.

Korobitsyn M.A, Jellema P \& Hirs G.G (1999). Possibilities for Gas Turbine and Waste Incineration Integration, Energy 24(9): 783-793. DOI: 10.1016/SO360-5442(99)00034-1.

Kuleape R, Cobbinah S.J, Dampare S.B, Duwiejuah A.B, Amoako E.E, \& Asare W (2014). Assessment of Energy recovery potential of solid waste generated in Akosombo,
Ghana, African. Environmental. Science \& Technology, 8 (5), 297-308. DOI: 10.5897/AJEST2014.1663.

Kumar J.S, Subbaiah K.V \& Prasada Rao P.V.V (2010). Waste to Energy - A Case Study of Eluru City, Andhra Pradesh, India; International Journal of Environmental Science; Vol 1, No 2, pp $151-162$.

Lauber J.D (2005). The Burning Issues of Municipal Solid Waste Disposal; What Works and What Doesn't; Invited Presentation at The Toronto City Council Municipal Solid Waste Conference: Advances in process and programs; 12 th may.

Minghua Z, Xiumin F, Rovetta A, Qichang H, Vicentini F, Bingkai L, Giusti A \& Yi L (2009). Municipal solid waste management in Pudong New Area, China. Waste Manage 29:1227-1233.Modern Engineering Research, Vol. 2 No. 5, pp. 3669-3672.

Nabegu, A.B (2009). Municipal Solid Waste Management in Kano and Katsina cities: A comparative Analysis. Journal of Geography and Development 2(2): 97-209.

(2011). Solid Waste and Its Implications for Climate Change in Nigeria. Journal for human Ecology 34(2): 67-73.

Nnaji C.C (2015). "Status of municipal solid waste generation and disposal in Nigeria", Management of Environmental Quality: An International Journal, Vol. 26 Issue 1 pp. $53-71$.

Nordi G.H, Palacios-Bereche R, Gallego A.G \& Nebra S.A (2017). Electricity production from Municipal Solid Waste in Brazil. Waste Management \& Research, pp 1-12. DOI: 10.1177/07342X17705721.

Nwambuonwo O. J. \& M Mughele E. S. (2012). Using geographic information system to select suitable landfill sites for megacities (Case Study of Lagos, Nigeria). Computing, Information Systems \& Development Informatics, 3(4), 48-56.

Ogbonna D, Ekweozor K \& Ig E (2002). Waste management: a tool for environmental protection in Nigeria. Journal of Environmental Science 3(1): 55-57.

Ogwueleka T.C (2003). Planning Model for Refuse Management. Journal of Science and Technology 3(2): 71-76.

(2009). Municipal Solid Waste Characteristics and Management in Nigeria. Iranian Journal of Environmental Health Science \& Engineering 6(3): 173-180.

Oucho J (1986). Population Studies and Research Institute, Our Common Future. Report of the World Commission on Environment, Public Hearing, Nairobi, 23 Sept. 1986 A/42/427.

Oumarou M, Dauda M, Abdulrahim A \& Abubakar A (2012). Characterization and generation of municipal solid waste in north central Nigeria, International Journal of Modern Engineering Research Vol.2, Issue.5, Sep-Oct. 2012 pp-36693672. ISSN: 2249-6645.

Prasada Rao P.V, Venkata K.S \&Sudhir J.K (2010). Waste to energy: A case study of Eluru, A.P, India. International Journal of Environmental Science and Development, 1(2): 151-162.

Punch Newspaper (2018): Plastic Pollution; Nigeria's Untapped Waste Wealth Fuel Environmental Disaster. Retrieved online; http://www.punchng.com. Accessed on 7/9/ 2018.

Revel M, Châtel A, \& Mouneyrac C. (2018). Micro (nano) plastics: A threat to human health? Current Opinion in Environmental Science \& Health, 1, 17-23. Retrieved 
online: https://www.sciencedirect.com/science/article/pii/ S2468584417300235. Accessed on 19/05/ 2019.

Ritchie H \& Roser M (2018). Plastic Pollution. Retrieved online; https://ourworldindata.org/plastic-pollution. Accessed on $9 / 05 / 2019$.

Rousta K \& Dahlén L (2015). Source separation of household waste; technology and social aspects. In: Taherzadeh M.J and Richards T (eds) Resource Recovery to Approach Zero Municipal Waste. Boca Raton: CRC Press, pp.61-77.

Sahara Reporters (2018), Visionscape, Ambode's New Waste management Company Struggles to keep Lagos Clean. Retrieved online; https://www.saharareporters.com. Accessed on $12 / 04 / 2019$.

Scavengers seek Conducive Environment to do Business (2018). Retrieved online; https:// www.environewsnigeria. $\mathrm{com} / \mathrm{scavengers-seek-conducive-environment-to-do-}$ business/. Accessed on 21/04/2019.

Somsak S (2014). Separation of PVC from PET/PVC mixtures using floatation by calcium Lignosulfonate Depressant. Engineering Journal, Vol. 18, issue 1, pp 45-53. ISSN 01258281, Doi: 8.4186/ej.2014.18.1.45

Suberu M.Y, Mokhtar A.S, \& Bashir N (2012). Renewable Power Generation Opportunity from Municipal Solid Waste: A Case Study of Lagos Metropolis (Nigeria). Journal of Energy Technologies and Policy: Vol. 2, No.2, 2012.

Tchobanoglous G, \& Kreith F (2002). Handbook of Solid Waste Management, 2nd ed. New York: McGraw-Hill.

, Theisen H, \& Vigil S.A (1993). Integrated solid waste management: engineering principles and management issues. McGraw-Hill Inc., New York.

The Guardian (2018). The ban on Scavengers in FCT, Nigeria. Retrieved online; https:// guardian.ng/opinion/the-ban-onscavengers-in-the-fct/. Accessed on 11/05/2019.

The Nation (2019). "Youths will be trained to convert waste to wealth". Retrieved online; https:// thenationonlineng.net/ waste to wealth/. Accessed on 1/06/2019.

Tsunatu D.Y, Tickson T.S, San K.D, \& Namo J.M (2015). Municipal Solid Waste as Alternative Source of Energy Generation: A Case Study of Jalingo Metropolis, Taraba State, Nigeria. International Journal of Engineering and Technology, Vol.5, No. 3, pp. 185-193. ISSN: 2049-3444.

UNEP (2005). Solid Waste Management (Vol. I). United Nations Environment Programme- International Environmental Technology Centre. CalRecovery, Inc.

UNU-WIDER (2010), "Solid wastes, poverty and the environment in developing country cities: challenges and opportunities", Working Paper No. 2010/23, United Nations University, World Institute for Development Economics Research, Helsinki.

USEPA (2005). Report of the municipal solid waste in the United States:2005 Facts and Figures. 5-15.

(2005). Report of the Municipal Solid Waste in the United States: 2005 Facts and Figures. pp 5-15.

Voelker B M. (2000). Waste-to- Energy, Solution for solid Waste Problem of 21st Century. http//www/p2pays.org/ ref/09/08624.pdf.14/03/08.

WEC (2013). "World Energy Resources; Waste to Energy," Vol. 7b, pp 2 -11.
World Bank (2012). "Urban Development Series: What is Waste; a global review of Solid Waste Management," No 15.

Xu W, Zhou C, Lan Y, Jin J \& Cao A (2015). An incentivebased source separation model for sustainable municipal solid waste management in China. Waste Management Resources; 33(5):469-76. DOI: 10.1177/0734242X15574979. 